\title{
Hubungan antara Usia, Paritas Dengan Persalinan Kala II Lama (Studi Kasus di RSUD dr. Moch. Soewandhie Surabaya)
}

\author{
Filderia Hutagalung ${ }^{1}$, Yefi Marliandiani ${ }^{2}$. \\ 1. Mahasiswa Program studi D-III Kebidanan Universitas PGRI Adi Buana Surabaya \\ 2. Tenaga Pengajar Program Studi D-III Kebidanan Universitas PGRI Adi Buana Surabaya
}

\begin{abstract}
ABSTRAK
Komplikasi persalinan merupakan salah satu penyebab kematian ibu, termasuk persalinan Kala II Lama. Persalinan Kala II Lama merupakan penyumbang urutan kelima terjadinya mortalitas ibu di Indonesia setelah perdarahan, eklampsi, infeksi dan komplikasi nifas. Adapun tujuan penelitian ini adalah untuk mengetahui hubungan antara usia, paritas dengan persalinan Kala II Lama.

Penelitian ini merupakan penelitian analitik dengan rancangan cross sectional. Populasi yang digunakan adalah semua ibu bersalin di RSUD dr. Moch. Soewandhie Surabaya, sebanyak 625 ibu bersalin yang diambil dari buku register persalinan bulan Januari-Maret 2011. Sampel ditentukan dengan menggunakan rumus $\mathrm{n}=\frac{\mathrm{N}}{1+\mathrm{N}\left(\mathrm{d}^{2}\right)}$, dengan jumlah sampel 240 ibu bersalin yang dipilih secara sampel random sampling. Ada dua variabel dalam penelitian ini yaitu variabel bebas (usia, paritas) dan variabel tergantung (persalinan kala II lama) dan istrumen yang digunakan adalah Rekam medik ruang bersalin RSUD dr. Moch. Soewandhie Surabaya. Analisis hubungan antara usia, paritas dan persalinan kala II lama digunakan analisis chi-square dengan taraf signifikan 0,05.

Hasil penelitian ini menunjukkan bahwa dari 240 ibu bersalin terdapat 17 ibu yang mengalami persalinan kala II lama. Dari ibu yang mengalami kala II lama sebagian besar adalah grande multi sebanyak 6 orang $(2,50 \%)$ dan ibu yang berusia > 35 sebanyak 9 orang $(4,17 \%)$. Hasil uji chisquare untuk usia didapatkan $\mathrm{x}^{2}=124,110$ dengan probabilitas (sig) $=0,000$ dan uji chi-square untuk paritas didapatkan $x^{2}=86,259$ dengan probabilitas (sig) $=0,000$. Maka artinya probabilitas $(\mathrm{sig})=0,000<0,05$. Maka hipotesis terbukti, artinya ada hubungan antara usia, paritas dengan persalinan kala II lama.
\end{abstract}

\section{Kata Kunci : Usia, Paritas, Kala II Lama}

\section{PENDAHULUAN}

Persalinan adalah suatu kejadian yang fisiologis yang akan dialami oleh wanita pada umumnya, namun pada prosesnya tidak jarang terjadi tindakan yang membuat persalinan tersebut lama (terhambat), $90 \%$ persalinan berjalan normal dan spontan tetapi dapat terjadi partus lama dan terlantar (Manuaba, 2001).

Berdasarkan data WHO tahun (2010) sebanyak 99\% kematian ibu akibat masalah persalinan atau kelahiran terjadi di negaranegara berkembang merupakan yang tertinggi dengan 450 kematian/100.000 kelahiran hidup, jika dibandingkan dengan rasio kematian ibu di negara-negara maju.

Angka Kematian Ibu karena persalinan lama di Indonesia menempati urutan kelima (5\%) setelah perdarahan (28\%), eklampsi (24\%), infeksi (11\%), komplikasi nifas (8\%) dari jumlah
AKI sebesar 228/100.000 kelahiran hidup (SDKI 2007) (www.scribd.com) tgl 10/3 2011 jam 15.30 WIB.

Angka kematian lbu (AKI) di Jawa Timur sebesar 83,14/100.000 kelahiran hidup (LB3KIA, 2008) menurut Renstra Dinkes Prov Jatim 2009 - 2014 (www.Dinkesjatim.go.id) 10/3/2011 jam 15.30 WIB

Persalinan lama adalah persalinan yang berjalan lebih dari 24 jam untuk primigravida dan 18 jam bagi multi gravida (Mochtar, 1998 : 384), dan disertai komplikasi ibu dan janin. Beberapa penyebab persalinan lama adalah kelainan letak janin, kelainan panggul ketidakseimbangan sepalopelvik, pimpinan persalinan yang salah dan primi tua primer atau sekunder dan kelainan kekuatan his dan menggedan (power) (Manuaba, 1998 : 292).Adapun sebab lain adalah ibu dengan umur terlalu muda kurang dari 20 tahun 
atau lebih dari 35 tahun, ketidakseimbangan antara panggul dan bagian terendah sering dijumpai pada ibu dengan tinggi badan kurang dari $150 \mathrm{~cm}$ yang mengakibatkan persalinan lama (Manuaba, 1999 : 175).

Berdasarkan data dari RSUD dr. Moch. Soewandhie Surabaya persalinan patologis masih sangat tinggi pada tahun 2009 dan 2010 bisa dilihat pada tabel 1.1 dan tabel 1.2 .

Tabel 1.1 Data jumlah persalinan di RSUD dr. Moch. Soewandhie Surabaya tahun 2009 dan tahun 2010

\begin{tabular}{|c|c|c|c|c|}
\hline \multirow{2}{*}{ Jenis Persalinan } & \multicolumn{2}{|c|}{ Tahun 2009 } & \multicolumn{2}{c|}{ Tahun 2010} \\
\cline { 2 - 5 } & $\Sigma$ & $\%$ & $\Sigma$ & $\%$ \\
\hline Normal & 1316 & 50,13 & 1044 & 42,47 \\
\hline Patologis & 1309 & 49,87 & 1414 & 57,53 \\
\hline Jumlah & 2625 & 100,00 & 2458 & 100,00 \\
\hline
\end{tabular}

Sumber : Rekam medik ruang bersalin RSUD dr. Moch. Soewandhie Surabaya

Dari tabel di atas jumlah persalinan patologis di RSUD dr. Moch. Soewandhie Surabaya mengalami kenaikan sebesar $7,66 \%$.

Tabel 1.2 Data Persalinan Patologis di RSUD dr. Moch. Soewandhie Surabaya tahun 2009 dan 2010

\begin{tabular}{|c|c|c|c|c|}
\hline \multirow{2}{*}{$\begin{array}{c}\text { Diagnosa } \\
\text { persalinan }\end{array}$} & \multicolumn{2}{|c|}{ Tahun 2009 } & \multicolumn{2}{c|}{ Tahun 2010 } \\
\cline { 2 - 5 } & $\Sigma$ & $\%$ & $\Sigma$ & $\%$ \\
\hline Kala II lama & $\mathbf{5 1}$ & $\mathbf{3 , 9 0}$ & $\mathbf{5 8}$ & $\mathbf{4 , 1 0}$ \\
\hline Letsu & 113 & 8,63 & 140 & 9,90 \\
\hline Bekas SC & 127 & 9,70 & 111 & 7,85 \\
\hline PEB & 118 & 9,01 & 83 & 5,87 \\
\hline Secondari Ares & 73 & 5,58 & 48 & 3,39 \\
\hline Grande Multi & 26 & 1,99 & 38 & 2,69 \\
\hline$\geq 35$ tahun & 13 & 0,99 & 54 & 3,82 \\
\hline KPP & 147 & 11,23 & 134 & 9,48 \\
\hline PER & 59 & 4,51 & 62 & 4,38 \\
\hline CPD & 38 & 2,90 & 54 & 3,82 \\
\hline APB & 32 & 2,44 & 62 & 4,38 \\
\hline HPP & 52 & 3,97 & 56 & 3,96 \\
\hline DII & 460 & 35,14 & 514 & 36,35 \\
\hline Jumlah & 1309 & 100,00 & 1414 & 100,00 \\
\hline
\end{tabular}

Sumber : Rekam medik ruang bersalin RSUD dr. Moch. Soewandhie Surabaya

Persalinan kala II lama termasuk sebagai penyumbang persalinan patologis tahun 2009
(3,90\%) dan tahun $2010 \quad(4,10 \%)$ dan mengalami peningkatan sebesar $(0,21 \%)$.

Tabel 1.3 Data persalinan kala II lama berdasarkan usia di RSUD dr. Moch. Soewandhie Surabaya tahun 2009 dan tahun 2010

\begin{tabular}{|c|c|c|c|c|}
\hline \multirow{2}{*}{ Usia } & \multicolumn{2}{|c|}{ Tahun 2009 } & \multicolumn{2}{c|}{ Tahun 2010 } \\
\cline { 2 - 5 } & $\Sigma$ & $\%$ & $\Sigma$ & $\%$ \\
\hline$<20$ & 15 & $29,41 \%$ & 25 & $43,10 \%$ \\
\hline $20-<35$ & 16 & $31,37 \%$ & 12 & $20,69 \%$ \\
\hline$>35$ & 20 & $39,22 \%$ & 21 & $36,21 \%$ \\
\hline
\end{tabular}

Sumber : Rekam medik ruang bersalin RSUD dr. Moch Soewandhie Surabaya

Data tahun 2009 berdasarkan usia ibu yang berusia $<20$ tahun sebanyak 15 ibu $(29,41 \%)$, ibu berusia $20-<35$ tahun 16 ibu $(31,37 \%)$, dan yang berusia $\geq 35$ tahun sebanyak 20 ibu $(39,22 \%)$, dan tahun 2010 berdasarkan usia, ibu yang berusia $<20$ tahun sebanyak 25 ibu (43,10\%), dan ibu berusia $20-<$ 35 tahun sebanyak 12 ibu $(20,69 \%)$, dan ibu berusia $\geq 35$ sebanyak 21 ibu $(36,21 \%)$.

Tabel 1.4 Data persalinan kala II lama berdasarkan paritas di RSUD dr. Moch. Soewandhie Surabaya tahun 2009 dan tahun 2010

\begin{tabular}{|c|c|c|c|c|}
\hline \multirow{2}{*}{ Paritas } & \multicolumn{2}{|c|}{ Tahun 2009 } & \multicolumn{2}{c|}{ Tahun 2010 } \\
\cline { 2 - 5 } & $\Sigma$ & $\%$ & $\Sigma$ & $\%$ \\
\hline Primipara & 31 & $60,78 \%$ & 29 & $50,00 \%$ \\
\hline Multipara & 8 & $15,69 \%$ & 14 & $24,14 \%$ \\
\hline Grandemulti & 12 & $23,53 \%$ & 15 & $25,86 \%$ \\
\hline
\end{tabular}

Sumber : Rekam medik ruang bersalin RSUD dr. Moch. Soewandhie Surabaya

Data tahun 2009 berdasarkan paritas, ibu primi para sebanyak 31 ibu $(60,78 \%)$, ibu multi para sebanyak 8 ibu (15,69\%), ibu grande multi sebanyak 12 ibu (23,53\%), sedangkan tahun 2010 berdasarkan paritas ibu primipara sebanyak 29 ibu $(50,00 \%)$, ibu multi para sebanyak 14 ibu $(24,14 \%)$, grande multi sebanyak 15 ibu $(25,86 \%)$.

Dari uraian di atas angka kejadian persalinan lama dan kejadiannya lebih banyak pada ibu primi para dan grande multi dan ibu usia $<20$ dan usia > dari 35 tahun sehingga perlu dilakukan penelitian tentang hubungan 
antara usia, paritas dengan persalinan kala II lama.

\section{BAHAN DAN METODE}

Pada penelitian ini rancang bangun yang digunakan adalah cross sectional.Populasi dalam penelitian ini semua catatan medik / dokumentasi pasien melahirkan di RSUD dr. Moch. Soewandhie pada Januari - Maret 2011 sebanyak 625 pasien. Teknik pemilihan sampel yaitu dengan simple random sampling. Besar sampel ditentukan dengan menggunakan rumus:

$$
\begin{aligned}
& \mathrm{n}=\frac{\mathrm{N}}{1+\mathrm{N}\left(\mathrm{d}^{2}\right)} \\
& \mathrm{n}=\frac{625}{1+(625)(0,05)^{2}} \\
& \mathrm{n}=\frac{625}{1+(625)(0,0025)} \\
& \mathrm{n}=\frac{625}{1+1,6} \\
& \mathrm{n}=\frac{625}{2,6} \\
& \mathrm{n}=240,4 \\
& \mathrm{n}=240 \\
& \text { Keterangan: } \\
& \mathrm{n} \quad: \text { Jumlah sampel } \\
& \mathrm{N} \quad: \text { Jumlah populasi } \\
& \mathrm{d} \quad: \text { Tingkat signifikan }(0,05)
\end{aligned}
$$

Jenis data yang digunakan dalam penelitian ini adalah data yang diambil dari dokumentasi atau rekam medik ibu bersalin di RSUD dr. Moch. Soewandhie Surabaya.Pengumpulan data dilakukan dengan mempelajari rekam medik (dokumentasi) ibu bersalin di RSUD dr. Moch. Soewandhie dengan cara menggunakan lembar pengumpulan data.Penelitian mencari dan mengumpulkan semua data ibu bersalin yang mengalami persalinan kala II lama dan kriterianya.Data yang diperoleh akan diklasifikasikan dan dihitung persentasinya kemudian diinterpretasikan sesuai dengan kriterianya dengan menggunakan skala menurut (Arikunto, 1998) sebagai berikut :

$100 \%$

$76 \%-99 \%$

$51 \%-75 \%$

$50 \%$

$26 \%-49 \%$

$1 \%-25 \%$

$0 \%$
= Seluruhnya

= Hampir seluruhnya

= Sebagian besar

= Setengahnya

= Hampir setengahnya

= Sebagian kecil

= Tidak ada satupun.
Dalam melakukan analisa data, peneliti menggunakan ilmu statistik terapan yang disesuaikan dengan tujuan yang hendak dianalisis (A. Aziz, 2007). Pada penelitian ini digunakan uji Chi-Square.

\section{HASIL DAN PEMBAHASAN}

Tabel 5.1 Distribusi Frekuensi lbu Bersalin berdasarkan Usia di RSUD dr. Moch.Soewandhie Surabaya pada Periode Bulan Januari s/d Maret 2011

\begin{tabular}{|c|l|c|c|}
\hline No & $\begin{array}{c}\text { Ibu bersalin } \\
\text { berdasarkan usia }\end{array}$ & $\Sigma$ & $\%$ \\
\hline 1 & $<20$ tahun & 29 & $12,08 \%$ \\
2 & $20-30$ tahun & 161 & $67,08 \%$ \\
3 & $31-35$ tahun & 40 & $16,67 \%$ \\
4 & $>35$ tahun & 10 & $4,17 \%$ \\
\hline & Jumlah & $\mathbf{2 4 0}$ & $100 \%$ \\
\hline
\end{tabular}

Berdasarkan tabel 5.1, dapat dijelskan bahwa dari 240 ibu yang melakukan persalinan di RSUD dr. Moch.Soewandhie Surabaya, sebagian besar berusia 20-30 tahun sebanyak 161 orang $(67,08 \%)$. Kondisi tersebut menunjukkan bahwa ibu yang bersalin di RSUD dr. Moch.Soewandhie Surabaya adalah ibu muda antara usia 20-30 tahun yang pada realitanya usia tersebut adalah usia yang sangat menguntungkan bagi seorang ibu yang sedang hamil dan ibu brsalin.

Tabel 5.2 Distribusi Frekuensi lbu Bersalin berdasarkan Paritas di RSUD dr. Moch.Soewandhie Surabaya pada Periode Bulan Januari s/d Maret 2011

\begin{tabular}{|c|l|c|c|}
\hline No & $\begin{array}{c}\text { Ibu bersalin } \\
\text { berdasarkan } \\
\text { paritas }\end{array}$ & $\Sigma$ & $\%$ \\
\hline 1 & Primipara & 95 & 39,58 \\
2 & Multipara & 13 & 57,92 \\
3 & Grande multipara & 6 & 2,50 \\
\hline & Jumlah & $\mathbf{2 4 0}$ & $100 \%$ \\
\hline
\end{tabular}

Tabel 5.2 menunjukkan bahwa sebagian besar ibu yang bersalin di RSUD dr. Moch.Soewandhie Surabaya sebagian besar adalah multipara sebanyak 139 orang ibu $(57,92 \%)$. Kondisi di atas menunjukkan bahwa ibu yang bersalin di RSUD dr. Moch.Soewandhie Surabaya kebanyakan adalah mereka yang pernah bersalin lebih dari satu kali atau bahkan 
lebih dari 2 kali hamil atau bersalin sampai pada stadium hidup.

Tabel 5.3 Distribusi Frekuensi Ibu Bersalin berdasarkan Persalinan Kala II Lama di RSUD dr. Moch.Soewandhie Surabaya pada Periode Bulan Januari s/d Maret 2011

\begin{tabular}{|c|c|c|c|}
\hline No & $\begin{array}{c}\text { Ibu bersalin } \\
\text { berdasarkan } \\
\text { persalinan }\end{array}$ & $\Sigma$ & $\%$ \\
\hline 1 & Kala II normal & 223 & 92,92 \\
\hline 2 & Kala II lama & 17 & 7,08 \\
\hline & Jumlah & 240 & $100 \%$ \\
\hline
\end{tabular}

Tabel 5.3 di atas menunjukkan bahwa sebagian besar ibu bersalin di RSUD dr. Moch.Soewandhie Surabaya adalah yang tergolong persalinan kala II normal sebanyak 223 ibu $(92,92 \%)$. Hal tersebut menunjukkan bahwa banyak di antara ibu yang bersalin di RSUD dr. Moch.Soewandhie Surabaya yang dalam persalinannya mulai dari pembukaan lengkap sampai bayi lahir pada primi $\leq 2$ jam dan pada multipara $\leq 1$ jam.

Tabel 5.4 Hubungan antara Usia dengan Persalinan Kala II Lama di RSUD dr. Moch.Soewandhie Surabaya pada Periode Bulan Januari s/d Maret 2011

\begin{tabular}{|l|c|c|c|c|c|c|}
\hline \multirow{2}{*}{ Usia } & \multicolumn{4}{|c|}{ Persalinan } & \multicolumn{2}{c|}{} \\
\cline { 2 - 7 } & \multicolumn{2}{|c|}{ Kala II normal } & \multicolumn{2}{c|}{$\begin{array}{l}\text { Kala II } \\
\text { lama }\end{array}$} & \multicolumn{2}{c|}{ Total } \\
\hline$<20$ thn & 23 & $79,3 \%$ & 6 & $20,7 \%$ & 29 & $100 \%$ \\
$20-30$ & 160 & $99,4 \%$ & 1 & $0,6 \%$ & 161 & $100 \%$ \\
$31-35$ & 39 & $97,5 \%$ & 1 & $2,5 \%$ & 40 & $100 \%$ \\
$>35$ thn & 1 & $10 \%$ & 9 & $90 \%$ & 10 & $100 \%$ \\
\hline Total & 223 & $29,29 \%$ & 17 & $7,08 \%$ & 240 & $100 \%$ \\
\hline
\end{tabular}

Berdasarkan tabel di atas dapat dijelaskan bahwa ibu bersalin di RSUD dr. Moch.Soewandhie Surabaya mayoritas berada pada golongan persalinan Kala II normal dengan jumlah sebanyak 223 ibu, hampir seluruhnya $(92,92 \%)$ yang didominasi oleh ibu yang berusia 20 tahun hingga 30 tahun dengan jumlah sebanyak 160 ibu $(71,7 \%)$ (sebagian besar dari ibu yang bersalin kala II normal). Sisanya adalah ibu yang bersalin dan masuk dalam golongan persalinan kala II lama dengan jumlah sebanyak 17 ibu atau sebesar 7,08\% dan didominasi oleh ibu yang berusia lebih dari 35 tahun yakni sebanyak 9 orang ibu yang usia di bawah 20 tahun sebanyak 6 orang.

Tabel 5.5 Hubungan antara Paritas dengan Persalinan Kala II Lama di RSUD dr. Moch.Soewandhie Surabaya pada Periode Bulan Januari s/d Maret 2011

\begin{tabular}{|c|c|c|c|c|c|c|}
\hline \multirow{3}{*}{$\begin{array}{c}\text { Paritas } \\
\text { Primipara }\end{array}$} & \multicolumn{4}{|c|}{ Persalinan } & \multirow{2}{*}{\multicolumn{2}{|c|}{ Total }} \\
\hline & \multicolumn{2}{|c|}{ Kala II normal } & \multicolumn{2}{|c|}{$\begin{array}{l}\text { Kala II } \\
\text { lama }\end{array}$} & & \\
\hline & 86 & $90,53 \%$ & 9 & $9,47 \%$ & 95 & $100 \%$ \\
\hline Multipara & 137 & 98,5 & 2 & 1,44 & 139 & $100 \%$ \\
\hline $\begin{array}{l}\text { Grande } \\
\text { multipara }\end{array}$ & & $0 \%$ & 6 & $100 \%$ & 6 & $100 \%$ \\
\hline Total & 223 & $92,92 \%$ & 17 & $7,08 \%$ & 240 & $100 \%$ \\
\hline
\end{tabular}

Berdasarkan tabel 5.5 di atas dapat diketahui bahwa 240 ibu bersalin di RSUD dr. Moch.Soewandhie Surabaya mayoritas berada pada golongan persalinan Kala II normal dengan jumlah 223 ibu, hampir seluruhnya (92,92\%) yang didominasi oleh ibu yang masuk dalam kategori multipara dengan jumlah 137 ibu, sebagian besar dari ibu yang bersalin kala II normal $(61,43 \%)$. Sisanya adalah ibu yang bersalin yang masuk golongan persalinan kala II lama dengan jumlah sebanyak $17 \mathrm{ibu}$, sebagian kecil $(7,08 \%)$ dan didominasi oleh ibu yang berusia kurang dari 20 tahun sebanyak 9 orang dan ibu grande multi sebanyak 6 orang.

Berdasarkan penyajian data yang kemudian dilakukan penyajian dengan menggunakan metode chi-square diperoleh hasil yang secara terperinci dijabarkan pada tabel sebagai berikut:

Tabel 5.6 Hasil uji Chi-SquareUsia dengan Persalinan Kala II Lama

\begin{tabular}{|c|c|c|}
\hline $\begin{array}{c}\text { Nilai Chi Square } \\
\left(\chi^{2}\right)\end{array}$ & $\begin{array}{c}\text { Probabilitas } \\
(\mathbf{s i g})\end{array}$ & Kesimpulan \\
\hline 124,110 & 0,000 & $\mathrm{H} 0$ ditolak \\
\hline
\end{tabular}

Sumber: Lampiran SPSS

Dari tabel hasil perhitungan uji statistik diatas diketahui nilai Chi-Square sebesar 124,110 dengan nilai probabilitas $(\mathrm{sig})=0.000$ dimana lebih kecil dari nilai 0,05 maka $\mathrm{HO}$ ditolak, yaitu ada hubungan antara Usia dengan Persalinan Kala II Lama di RSUD dr. Moch.Soewandhie Surabaya

Berdasarkan penyajian data yang kemudian dilakukan penyajian dengan menggunakan metode chi-square diperoleh hasil 
yang secara terperinci dijabarkan pada tabel sebagai berikut:

Tabel 5.7 Hasil uji Chi-Square Paritas dengan Persalinan Kala II Lama

\begin{tabular}{|c|c|c|}
\hline $\begin{array}{c}\text { Nilai Chi-Square } \\
\left(\chi^{\mathbf{2}}\right)\end{array}$ & $\begin{array}{c}\text { Probabilitas } \\
(\mathbf{s i g})\end{array}$ & Kesimpulan \\
\hline 86,259 & 0,000 & H0 ditolak \\
\hline
\end{tabular}

Sumber: Lampiran SPSS

Dari tabel hasil perhitungan uji statistik diatas diketahui nilai Chi-Square sebesar 86,259 dengan nilai probabilitas $(\mathrm{sig})=0.000$ dimana lebih kecil dari nilai 0,05 maka HO ditolak, yaitu ada hubungan antara paritas dengan Persalinan Kala II Lama di RSUD dr. Moch.Soewandhie Surabaya

Adanya hubungan antara usia dengan persalinan kala II lama tersebut sesuai dengan teori yang dikemukakan oleh obstetri William (2005) yang menyatakan bahwa pada penelitianpenelitian sebelumnya yang mengisyaratkan bahwa wanita yang berusia sekitar 35 tahun ke atas lebih beresiko tinggi mengalami penyulit obstetri serta morbiditas dan mortalitas peri natal karena uterus yang tidak lentur atau elastis sehingga memiliki kemungkinan terjadi persalinan kala II lama.

Oleh karena itu dalam penelitian ini banyak ibu yang berusia 20 hingga 30 tahun dengan jumlah sebanyak 160 ibu yang bersalin di RSUD dr. Moch.Soewandhie Surabaya, karena ingin mempersiapkan proses persalinan mereka dengan baik terhindar dari resiko-resiko yang tidak dinginkan terjadi pada dirinya juga janinnya. Sebab menurut Poedji Rochjati (2003) bahwa ibu hamil yang berusia lebih dari 35 tahun memiliki resiko tinggi terhadap kehamilan dan persalinan, dimana pada usia tersebut terjadi perubahan pada jaringan alat-alat reproduksi dan jalan lahir tidak lentur dan bahaya yang dapat terjadi pada kelompok ini adalah antara lain : persalinan lama akibat power yang antara lain tenaga ibu dan kelainan-kelainan HIS.

Adanya hubungan antara paritas dengan persalinan kala II lama tersebut didukung oleh teori yang dikemukakan oleh Cunning Cam dkk dalam bukunya Obstetric William (2005) yang menyatakan bahwa wanita dengan Paritas tinggi beresiko mengalami persalinan lama karena disebabkan uterus mengalami kekendoran pada dinding rahim, jika dalam penelitian ini ditemukan ibu yang paritas tinggi tergolong dalam grande multi atau ibu yang melahirkan lebih dari 5 kali stadium hidup, karena ibu sering melahirkan maka kemungkinan akan banyak ditemui keadaan kesehatan terganggu (anemia atau kurang gizi).

Kekendoran pada dinding perut, tampak ibu dengan perut menggantung dan kekendoran pada dinding rahim. Bahaya yang dapat mengancam pada kelompok ini adalah robekan pada dinding rahim, kelainan his (atomia uteri), perdarahan post partum (pasca persalinan), persalinan lama, kelainan letak, dll.

Pada penelitian ini juga ditemukan ibu yang paritas rendah misalnya primi juga mengalami kala II lama sebanyak 9 orang, ini bisa terjadi sesuai data yang ada di RSUD dr. Moch. Soewandhie adalah ibu primi atau yang pertama bersalin dengan usia di bawah 20 tahun. Karena ibu bersalin dengan primi gravida dan usianya kurang dari 20 tahun, sangat kompleks masalahnya. $\mathrm{Di}$ samping alat reproduksinya yang belum siap, sering terjadi gangguan kesehatan misalnya (anemia, ibu KEK) sehingga terjadi gangguan pada power (tenaga ibu sendiri) dan ada kemungkinan gangguan psikologis belum siap hamil, misalnya pada kasus perkosaan dan akibat seks bebas atau yang dikatakan dengan hamil di luar nikah.

\section{SIMPULAN DAN SARAN}

Berdasarkan hasil pembahasan pada bab sebelumnya dapat diperoleh kesimpulan sesuai dengan tujuan penelitian pada Januari s/d Maret 2011 di RSUD dr. Soewandhie Surabaya adalah:

Terdapat hubungan antara usia dengan persalinan kala II lama di mana nilai Chi-Square sebesar 124,110 dengan nilai probabilitas $(\mathrm{sig})=$ 0,000 lebih kecil dari nilai 0,05 maka $\mathrm{HO}$ ditolak.

Terdapat hubungan antara paritas dengan persalinan kala II lamadimana nilai Chi-Square sebesar 86,259 dengan nilai probabilitas $($ sig) = 0,000 lebih kecil dari nilai 0,05 maka $\mathrm{H} 0$ ditolak.

Berdasarkan hasil penelitian tersebut maka diharapkan :

1. Hasil penelitian ini dapat digunakan sebagai bahan masukan dalam mengambil keputusan dalam meningkatkan mutu pelayanan kesehatan pada ibu bersalin sehingga dapat mencegah terjadinya kala II lama terutama ibu bersalin usia < dari 20 tahun dan lebih dari 35 tahun dan ibu dengan paritas tinggi atau ibu grande multi, sehingga mengurangi kematian ibu dan bayi di tempat pelayanan. 
2. Hasil penelitian ini dapat dijadikan sebagai tambahan koleksi bacaan di perpustakaan institusi pendidikan.

3. Hasil penelitian ini dapat dijadikan dasar bagi peneliti selanjutnya dengan menggunakan metode penelitian yang lebih representatif sehingga hasilnya lebih valid.

\section{DAFTAR ACUAN}

Bibiliung,2008,Hamil di Usia 20, 30 atau 40. (Internet) available from (http://www.bibilung.wordpress.com) (acrssted February $18^{\text {th }}, 2007$ )

Manuaba, 1998, IImu Kebidanan, Penyakit Kandung dan Keluarga Berencana untuk Pendidikan Bidan, Jakarta : EGC.

Manuaba, 2002, IImu Kebidanan, Penyakit Kandung dan Keluarga Berencana untuk Pendidikan Bidan, Jakarta : EGC.

Manuaba, 2007, Pengantar Kuliah Obstetri, Jakarta : EGC.

Manuaba, 2008, Gawat Darurat Obstetri Ginekologi dan Obstetri Ginekologi Sosial untuk Profesi Bidan, Jakarta : EGC.

Mochtar R, 1998, Sinopsis Obstetri Fisiologi Patologi, Jakarta : EGC.

Nursalam, 2000, Metode Penelitian, Jakarta : PT. Rineka Cipta.

Oxorn H, 2003, Patologi Fisiologi Persalinan, Jakarta : Yayasan Essentia Media
Purnomo W, 2007, Metodologi

Penelitian, Surabaya : Airlangga University Press.

Rochjati, Poedji, 2003, Skrining Antenatal Pada Ibu Hamil, Surabaya : Airlangga University Press.

Rochjati, Poedji, 2004, Rujukan Terencana Dalam Sistem Rujukan Paripurna Terpadu Kabupaten / Kota, Surabaya : Airlangga University Press.

Saifuddin SA, 2002, Buku Acuan Pelayanan Kesehatan Maternal dan Neonatal, Jakarta : YBPSP.

Saifuddin SA, 2001, Buku Acuan Pelayanan Kesehatan Maternal dan Neonatal, Jakarta : YBPSP.

Sarwono, 2005, IImu Kebidanan, Jakarta : YBPSP.

Simkim. Penny, 2007, Panduan Lengkap Kehamilan dan Persalinan. Jakarta : YBPSP.

Varney, 2006, Asuhan Kebidanan, Jakarta : EGC.

Wiknjosastro H, 2007, Asuhan Kebidanan Normal, Jakarta : JNPK-KR

Wiknjosastro H, 2006, IImu Kebidanan, Jakarta : YBPSP.sia, Paritas, Kala II Lama. 


\title{
Hubungan antara perilaku ibu tentang kebersihan dan frekuensi kejadian Gastroentritis pada balita usia 1 - 3 tahun di RS Adi Husada Kapasari Surabaya
}

\author{
Ernawatik¹, Nyna Puspitaningrum²
}

1. Mahasiswi Program Studi D-III Kebidanan Universitas PGRI Adi Buana Surabaya

2. Tenaga Pengajar Program Studi D III Kebidanan Universitas PGRI Adi Buana Surabaya

\begin{abstract}
ABSTRAK
Gastroentritis merupakan penyebab utama morbiditas dan mortalitas pada anak di seluruh dunia, dimana pada balita daya tahan tubuh masih sangat rentan terhadap penyakit. Selain itu penyakit gastroentritis pada balita juga dipengaruhi oleh perilaku ibu, karena balita sangat tergantung pada ibu dalam melakukan kegiatan sehari-hari. Tujuan penelilian ini adalah untuk menganalisa hubungan perilaku ibu tentang kebersihan dan frekuensi kejadian gastroentritis pada balita usia 1-3 tahun. Jenis penelitian yang digunakan analitik kuantitatif dengan desain penelitian cross sectional yang dilaksanakan pada tanggal 1 April - 31 Mei 2010 di RS Adi Husada Kapasari, uji statistik dengan menggunakan sperman rank. Berdasarkan hasil penelitian diperoleh hasil bahwa sebagian besar (56\%) ibu berperilaku tidak sehat dan sebagian besar (60\%) balita usia 1-3 tahun terserang GE $>3 x$ dalam kurun waktu 3 bulan. Dan hasil sperman rank didapatkan $t_{\text {hitung }} 9,39>t_{\text {tabel }} 2,048$, jadi $H_{o}$ ditolak dan $\mathrm{H}_{1}$ diterima, yang menyatakan terdapat hubungan perilaku ibu tentang kebersihan dan frekuensi kejadian GE pada balita usia 1-3 tahun. Oleh sebab itu perlu adanya penyuluhan tentang pentingnya membiasakan ibu untuk berperilaku hidup sehat sebagai upaya untuk pencegahan penyakit gastroenteritis pada balita.
\end{abstract}

Kata Kunci : Perilaku, Gastroentritis, balita usia 1 - 3 tahun

\section{PENDAHULUAN}

Angka kematian pada balita di Indonesia pada tahun 2007 masih cukup tinggi yaitu 45:1000 kelahiran hidup. Penyebab kematian anak adalah infeksi pernafasan akut, komplikasi pasca persalinan, diare, tetanus, meningitis, thypus, malaria serta kekurangan gizi (www.tempointeraktif.com). Menurut riset kesehatan dasar (Riskesdas) tahun 2007 beberapa penyakit utama yang menjadi penyebab kematian pada balita adalah penyakit diare sebanyak 25,2\%; pneumonia $15,5 \%$; Demam Berdarah Dengue 6,8\% dan campak sebanyak 5\% (www.infodokterku.com).

Penyakit diare atau dalam bidang kesehatan lebih sering di sebut dengan istilah gastroentritis, hingga kini masih menjadi salah satu penyebab utama morbiditas dan mortalitas pada anak diseluruh dunia yang menyebabkan kejadian sakit dan 3-4 kasus kematian setiap tahunnya (Nelson, 1999 : 889). GastroEntritis (GE) sering dianggap penyakit sepele, pada tingkat global dan nasional fakta menunjukkan sebaliknya. Di Asia, Afrika dan Amerika Latin diperkirakan 3-5 milliar episode diare menimbulkan 5-6 juta kasus kematian. (Rudolph, 2006 : 719), sedangkan di Indonesia diperkirakan terdapat lebih 60 juta kejadian GE setiap tahunnya.

Sebagian besar penderitaadalah anak-anak dibawah usia 5 tahun( $60-80 \%$ ), sehingga terdapat kurang lebih 40 juta kejadian GE pada setiap tahunnya. (Sudarmo, M.S., dkk, 2004 : 41). Menurut catatan WHO, GE membunuh 2,2 juta anak di dunia setiap tahunnya, sedangkan di Indonesia menurut survei kesehatan nasional (Surkesnas) tahun 2001, GE merupakan 
penyebab kematian kedua terbesar pada balita (www. medicastore.com).

GE merupakan infeksi saluran pencernaan, dimana keadaan frekuensi buang air besar lebih dari 4x pada bayi dan lebih dari 3x pada anak, konsistensi feaces encer, dapat berwarna hijau atau dapat pula bercampur lendir dan darah atau lendir saja. (Ngastiyah 1997 : 143). Di Negara berkembang maupun negara maju, rotavirus merupakan penyebab GE yang penting pada bayi dan balita, yang ditularkan melalui rute masa oral atau fecal-oral (Rudolph, 2006 : 719). Pada umumnya penyakit GE terjadi pada lingkungan yang padat penduduk, tinggal berdesakan, kebersihan yang buruk dan sanitasi yang jelek, serta terjadi pada saat pergantian musim (Wong, 2006 : 999).

Berbagai perilaku kebersihan ibu seperti kebiasaan tidak mencuci tangan dengan sabun sesudah buang air besar atau sebelum menjamah makanan, memudahkan penularan penyakit GE yang ditularkan melalui fecal-oral, tidak membiasakan balita buang air besar di toilet, dimana pada tinja terdapat rotavirus yang dapat hidup berminggu-minggu di luar tubuh manusia serta penggunaan botol susu yang tidak disterilkan kembali setelah dipakai kemungkinan meningkatkan resiko terjadinya diare pada bayi dan balita (Nursalam, dkk, 2005 : 169). Balita dapat mengalami lebih dari satu kali kejadian diare setiap tahunnya (Sudarmo. M.s, dkk, 2004 : 41).

Menurut data survey baseline Environment Services Program (ESP - USAID) tahun 2006, fakta menunjukan bahwa masih rendahnya kebiasaan untuk membersihkan tangan dengan menggunakan sabun, pada saat penting di masyarakat yaitu sebelum makan 14,3\%; sesudah buang air besar 11,7\%; setelah memberi minum bayi $8,9 \%$; sebelum menyuapi anak $7,4 \%$ dan sebelum menyiapkan makanan $6 \%$. (www.kr.co.id).

Di RS Adi Husada Kapasari Surabaya, angka kejadian GE merupakan angka yang tertinggi di banding penyakit lainnya di ruang rawat inap anak. Berdasarkan data yang diperoleh di ruang rawat inap anak RS. Adi
Husada Kapasari Surabaya pada tahun 2007 2009 :

- Tahun 2007 jumlah seluruh penderita di ruang rawat inap anak 1.493, jumlah pasien GE sebanyak 414 (27,7\%), dengan jumlah pasien GE pada balita usia 1-3 tahun, 156 $(39,6 \%)$.

- Tahun 2008 jumlah seluruh penderita di ruang rawat inap anak 1.532 , jumlah pasien GE sebanyak 430 (28,1\%), dengan jumlah pasien GE pada balita usia 1-3 tahun, 139 (34,7\%).

- Tahun 2009 jumlah seluruh penderita di ruang rawat inap anak 1.516 , jumlah pasien GE sebanyak 447 (29,5\%), dengan jumlah pasien GE pada balita usia 1-3 tahun, 194 (45,3\%).

Berdasarkan uraian diatas dapat disimpulkan bahwa kebersihan yang buruk dan sanitasi yang jelek merupakan pokok utama timbulnya GE, maka dengan dilaksanakannya kebiasaan untuk membersihkan tangan dengan menggunakan sabun serta menjaga kebersihan dapat mengurangi faktor pendorong GE. Sehingga dapat ditarik suatu rumusan masalah yakni apakah ada hubungan antara perilaku ibu tentang kebersihan dan frekuensi kejadian GE pada balita usia 1-3 tahun di RS Adi Husada kapasari Surabaya ? Tujuan umum penelitian adalah mengetahui hubungan antara perilaku ibu tentang kebersihan dan frekuensi kejadian GE pada balita usia 1-3 tahun. Tujuan khusus dari penelitian ini adalah :

- Mengidentifikasi frekuensi kejadian Gastroentritis pada balita usia 1-3 tahun di RS Adi Husada Kapasari Surabaya.

- Mengidentifikasi perilaku ibu tentang kebersihan yang balitanya menderita Gastroentritis di RS Adi Husada Kapasari Surabaya.

- Menganalisis hubungan perilaku ibu tentang kebersihan dan frekuensi kejadian Gastroentritis pada balita usia 1-3 tahun di RS Adi Husada Kapasari Surabaya.

\section{BAHAN DAN METODE}

Jenis penelitian yang digunakan adalah analitik kuantitatif dengan desain penelitian cross sectional dimana variabel-variabel yang 
termasuk faktor dan variabel yang termasuk efek di observasi sekaligus pada saat yang sama. Populasi penelitian ini adalah seluruh ibu yang balitanya menderita GE dan berusia 1-3 tahun di ruang rawat inap anak di RS Adi Husada Kapasari Surabaya.Total sampel yaitu 30 orang dengan teknik sampling jenuh.

Variabel independent dalam penelitian ini adalah perilaku ibu tentang kebersihan yang balitanya menderita GE dan variabel dependen yaitu frekuensi kejadian GE pada balita usia 1-3 tahun.

Prosedur pengumpulan data dengan menggunakan angket. Yang berisi 10 pertanyaan tentang perilaku ibu dengan 3 pilihan jawaban :

1. Jawaban 1 nilai kurang;

2. Jawaban 2 nilai cukup;

3. Jawaban 3 nilai baik

Skor total : 30

Dari penilaian perilaku ibu diatas maka perumusan skor sebagai berikut :

- $15-20$ : perilaku ibu tidak sehat.

- 21-25: perilaku ibu kurang sehat.

- 26-30 : perilaku ibu sehat

Satu pertanyaan tentang kejadian GE pada balita dengan 3 pilihan jawaban sebagai berikut :

1. Bila balita terserang GE 1 kali dalam kurun waktu 3 bulan nilai 3;

2. Bila balita terserang GE 2 - 3 kali dalam kurun waktu 3 bulan nilai 2;

3. Bila balita terserang GE $>3$ kali dalam kurun waktu 3 bulan nilai 1 .

Skor total : 3 .

Gambar 1 - Kerangka konseptual hubungan perilaku ibu tentang kebersihan dan frekuensi kejadian GE pada balita usia 1-3 tahun.

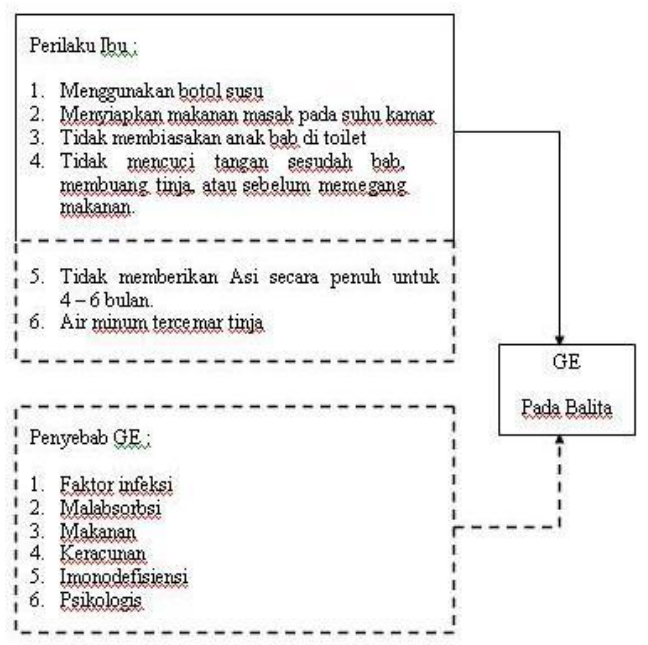

Keterangan :

$\square$ : Diteliti

: Tidak di teliti

Pada gambar 1 dapat dijelaskan bahwa GE pada balita dapat disebabkan oleh faktor infeksi, malabsorbsi, makanan, keracunan, imuno defisiensi dan psikologis dan faktor perilaku ibu tentang kebersihan yang dapat meningkatkan kejadian GE pada balita. Pada penelitian ini penulis hanya membatasi subjek yang di teliti yaitu semua ibu yang balitanya menderita penyakit GE dan semua balita yang berusia 1-3 tahun menderita GE di ruang rawat inap anak RS Adi Husada Kapasari Surabaya.

Dalam penelitian ini di rumuskan hipotensis sebagai berikut :

$\mathrm{H}_{1}$ ada hubungan antara perilaku ibu tentang kebersihan dan frekuensi kejadian GE pada Balita usia 1-3 tahun di RS Adi Husada Kapasari Surabaya.

Analisis untuk mengetahui hubungan menggunakan Uji korelasi Sperman Rank dengan tingkat kemaknaan $\alpha 0,05$ dengan rumus

$\mathrm{rs}=\frac{\sum x^{2}+\sum y^{2}-\sum d i^{2}}{2 \sqrt{\sum x^{2} \sum y^{2}}}$

Keterangan :

rs = Koefisien korelasi Sperman Rank

$d i=$ Selisih setiap pasangan rank

Pengujian para meter koefisien korelasi menggunakan :

$\mathrm{t}=\frac{\mathrm{rs} \sqrt{\mathrm{n}-2}}{\sqrt{1-\mathrm{r}_{\mathrm{s}}^{2}}}$

Untuk mengetahui ada tidaknya hubungan kedua variabel dibandingkan dengan tabel $\mathrm{t}$.

Keterangan :

$\mathrm{H}_{\mathrm{o}}$ ditolak jika $\mathrm{t}>$ nilai $\mathrm{t}$ tabel

$\mathrm{H}_{1}$ diterima jika $\mathrm{t}>$ nilai $\mathrm{t}$ table

\section{HASIL DAN PEMBAHASAN}

Berikut ini uraian hasil penelitian yang telah dilakukan di ruang rawat inap anak RS Adi Husada Kapasari Surabaya 
Tabel 1 - Tabel distribusi frekuensi berdasarkan perilaku ibu tentang kebersihan di ruang rawat inap anak RS Adi Husada Kapasari

\begin{tabular}{ccc}
\hline $\begin{array}{c}\text { Perilaku Ibu } \\
\text { tentang } \\
\text { Kebersihan }\end{array}$ & Frekuensi (f) & Prosentase (\%) \\
\hline $\begin{array}{c}\text { Perilaku tidak } \\
\text { sehat }\end{array}$ & 17 & 57 \\
$\begin{array}{c}\text { Perilaku kurang } \\
\text { sehat }\end{array}$ & 5 & 17 \\
$\begin{array}{c}\text { Perilaku sehat } \\
\text { Jumlah }\end{array}$ & 8 & 26 \\
\hline
\end{tabular}

Dari table 1 dapat dijelaskan sebagian besar 17 orang (57\%) berperilaku hidup tidak sehat.

Tabel 2 - Tabel distribusi frekuensi berdasarkan frekuensi kejadian GE pada balita usia 1-3 tahun di ruang rawat inap anak RS Adi Husada

\section{Kapasari}

\begin{tabular}{ccc}
\hline $\begin{array}{c}\text { Frekuensi kejadian GE pada } \\
\text { balita usia 1-3 tahun }\end{array}$ & $\begin{array}{c}\text { Frekuensi } \\
\text { (f) }\end{array}$ & $\begin{array}{c}\text { Prosentase } \\
\text { (\%) }\end{array}$ \\
\hline $\begin{array}{c}\text { Terserang GE > 3x dalam kurun } \\
\text { waktu 3 bulan }\end{array}$ & 18 & 60 \\
$\begin{array}{c}\text { Terserang GE 2-3x dalam kurun } \\
\text { waktu 3 bulan }\end{array}$ & 7 & 23 \\
$\begin{array}{c}\text { Terserang GE 1x dalam kurun } \\
\text { waktu 3 bulan }\end{array}$ & 5 & 17 \\
\hline Jumlah & 30 & 100 \\
\hline
\end{tabular}

Berdasarkan table 2 dapat dijelaskan sebagian besar 18 balita (60\%) terserang penyakit GE lebih dari 3x dalam kurun waktu 3 bulan.
Tabel 3 - Tabulasi silang perilaku ibu tentang kebersihan dan frekuensi kejadian GE di ruang rawat inap anak RS Adi Husada Kapasari

\begin{tabular}{|c|c|c|c|c|c|c|c|c|}
\hline $\begin{array}{r}\text { Frekuensi } \\
\text { kejadian } \\
\text { GE }\end{array}$ & \multicolumn{2}{|c|}{$\begin{array}{c}\text { Terseran } \\
\mathbf{g} \\
\text { GE }>\mathbf{3 x}\end{array}$} & \multicolumn{2}{|c|}{$\begin{array}{c}\text { Terseran } \\
\text { g GE 2- } \\
3 \mathbf{x}\end{array}$} & \multicolumn{2}{|c|}{$\begin{array}{c}\text { Terseran } \\
\text { g GE 1x }\end{array}$} & \multicolumn{2}{|c|}{ Total } \\
\hline & $f$ & $\%$ & f & $\%$ & $f$ & $\%$ & f & $\%$ \\
\hline $\begin{array}{c}\text { Perilaku } \\
\text { tidak sehat }\end{array}$ & $\begin{array}{l}1 \\
7\end{array}$ & 100 & 0 & 0 & 0 & 0 & $\begin{array}{l}1 \\
7\end{array}$ & 100 \\
\hline $\begin{array}{c}\text { kurang } \\
\text { sehat }\end{array}$ & 1 & 20 & 4 & 80 & 0 & 0 & 5 & 100 \\
\hline $\begin{array}{l}\text { Perilaku } \\
\text { sehat }\end{array}$ & 0 & 0 & 3 & 37 & 5 & 63 & 8 & 100 \\
\hline Jumlah & $\begin{array}{l}1 \\
8\end{array}$ & & 7 & & 5 & & $\begin{array}{l}3 \\
0\end{array}$ & \\
\hline$\alpha=0,05$ & & & & 9,39 & & & . & \\
\hline
\end{tabular}

Dari hasil analisa dengan menggunakan uji statistic sperman rank dengan kemaknaan $\alpha=$ 0,05 didapatkan bahwa $t_{\text {hitung }} 9,39>t_{\text {tabel }} 2,048$ dapat disimpulkan $\mathrm{Ho}$ ditolak dan $\mathrm{H}_{1}$ diterima hal ini terdapat hubungan antara perilaku ibu tentang kebersihan dan frekuensi kejadian GE pada balita usia 1-3 tahun di ruang rawat inap anak RS Adi Husada Kapasari bahwa sebagian besar perilaku ibu tidak sehat menyebabkan 17 balita terserang penyakit GE $>3 x$ dalam kurun waktu 3 bulan.

Berdasarkan hasil penelitian, terdapat hubungan antara perilaku ibu tentang kebersihan dan frekuensi kejadian GE pada balita usia 1-3 tahun di ruang rawat inap anak RS Adi Husada Kapasari Surabaya yang telah diuji dengan menggunakan sperman rank. Data yang didapatkan di ruang rawat inap anak RS Adi Husada Kapasari sebagian besar (57\%) ibu berperilaku tidak sehat dan sebagian besar $(60 \%)$ balita terserang penyakit GE $>3 x$ dalam kurun waktu 3 bulan.

Dari hasil sperman rank dengan taraf signifikan $\alpha 0,05(5 \%)$, nilai $t_{\text {hitung }}$ sebesar 9,39 
sedangkan nilai $t_{\text {tabel }} 2,048$. Karena nilai $t_{\text {hitung }}>$ dari $t_{\text {tabel }}(9,39>2,048)$ maka $\mathrm{H}_{\circ}$ ditolak dan $\mathrm{H}_{1}$ diterima sehingga dapat disimpulkan, terdapat hubungan antara perilaku ibu tentang kebersihan dan frekuensi kejadian GE pada balita usia 1 - 3 tahun, dapat dikatakan bahwa ibu yang berperilaku tidak sehat menyebabkan balita lebih rentan dan lebih sering terserang penyakit GE.

Hal ini sesuai dengan (Sulika, dkk, 2002) bahwa perilaku sehat dipengaruhi adanya faktor internal keluarga seperti halnya ibu atau masyarakat yang mempermudah untuk berperilaku hidup sehat. Seorang ibu memegang peranan penting bagi kesehatan balitanya, dimana pada balita usia 1-3 tahun sangat tergantung pada ibu dalam melakukan aktivitas sehari-hari. Perilaku hidup ibu yang tidak sehat seperti penggunaan botol susu dan cara penyeterilan botol susu yang salah, tidak membiasakan balita untuk BAB di toilet, membuang tinja selain di toilet, tidak mencuci tangan sesudah buang air besar, sesudah membuang tinja atau sebelum memegang makanan merupakan faktor resiko yang dapat meningkatkan terjadinya GE pada balita. (Nursalam, dkk, 2005).

Berdasarkan hasil penelitian ini ditemukan pula sebanyak 3 balita yang terserang penyakit GE 2-3x dalam kurun waktu 3 bulan pada ibu yang mempunyai perilaku sehat. Hal ini dikarenakan GE pada balita tidak hanya disebabkan karena perilaku ibu saja, tetapi juga dapat dipengaruhi oleh faktor lain, yaitu infeksi enteral atau parenteral, malabsorsi karbohidrat, lemak, protein dan keracunan maupun disebabkan oleh defisiensi imun terutama SIgA serta sanitasi yang jelek dan tingkat pendidikan yang rendah, namun dalam penelitian ini faktorfaktor tersebut tidak diteliti.

\section{SIMPULAN DAN SARAN}

Berdasarkan data analisis maka dapat disimpulkan sebagai berikut :

1. Sejumlah 17 responden (57\%) ibu berperilaku hidup tidak sehat yang balitanya berusia 1-3 tahun menderita GE di ruang rawat inap anak RS Adi Husada Kapasari Surabaya.
2. Sejumlah 18 responden $(60 \%)$ balita usia 1-3 tahun terserang penyakit $\mathrm{GE}>3 \mathrm{x}$ dalam kurun waktu 3 bulan.

3. Terdapat hubungan antara perilaku ibu tentang kebersihan dan frekwensi kejadian GE pada balita usia 1-3 tahun di ruang rawat inap anak RS Adi Husada Kapasari Surabaya.

Berdasarkan hasil penelitian diatas maka diharapkan bagi masyarakat, khususnya :

1. Bagi ibu, diharapkan dapat meningkatkan perilaku hidup sehat, sebagai upaya untuk mencegah penyakit GE pada balita, yang dapat diawali dengan hal yang paling sederhana yaitu membiasakan cuci tangan dengan sabun.

2. Bagi perawat, diharapkan perawat dapat memberikan penyuluhan kepada ibu tentang pentingnya kebiasaan hidup sehat, pencegahan serta penularan penyakit GE sehingga dapat mengurangi periode kejadian penyakit GE pada balita serta memberikan asuhan keperawatan secara menyeluruh.

3. Bagi Rumah Sakit, diharapkan untuk dapat meningkatkan pengetahuan perawat agar mampu memberikan pelayanan keperawatan yang optimal melalui seminar-seminar atau pelatihan. Serta pemasangan poster tentang cara mencuci tangan yang benar, sanitasi lingkungan, cara pencucian dan penyeterilan botol susu, yang dapat dengan mudah dibaca atau dipahami oleh orang tua khususnya ibu balita.

\section{DAFTAR ACUAN}

Eko Budiarto, 2003 : Metodologi Penelitian Kedokteran Sebuah Pengantar, Jakarta : GEC.

Hartanto Sunardi dan Wara Pramesti, 2008 : Statistika Surabaya University Press Adi Buana.

Heri Purwanto, 1998 : Pengantar Perilaku Manusia, Jakarta : EGC.

Hurlock, B., 1998 : Perkembangan Anak, Jakarta : Erlangga.

Machfoedz, I, dkk, 2005 : Pendidikan Kesehatan Bagian dari Promosi Kesehatan, Yogyakarta: Fitramaya. 
Nelson, 1999 : Ilmu Kesehatan Anak, Jakarta : EGC.

Ngastiyah, 1997 : Perawatan Anak Sakit, Jakarta : EGC.

Ngastiyah, 2005 : Perawatan Anak Sakit, Jakarta : EGC.

Nursalam, dkk., 2005 : Asuhan Keperawatan Bayi dan Anak, Jakarta : Salemba Medika.

Nursalam, 2008 : Konsep dan Penerapan Metodologi Penelitian IImu Keperawatan, Jakarta : Salemba Medika.

Rudolph, C., 2006 : Buku Ajar Pediatri Rudolph, Jakarta : EGC.

Sastroasmoro dan Sofyan Ismael, 2002 : Dasardasar Metodologi Penelitian Klinis, Jakarta : CV Sagung Seto.

Soekidjo Notoatmodjo, 2003 : Pendidikan dan Perilaku Kesehatan, Jakarta : Rineka Cipta

Soekidjo Notoatmodjo, 2005 : Metodologi Penelitian Kesehatan, Jakarta : Rineka Cipta.

Soetjiningsih, 1995 : Tumbuh Kembang Anak, Jakarta : EGC

Sudarmo, S., dkk, 2004 : Sindroma Diare RSUD Dr. Soetomo, Surabaya : Fakultas Kedokteran Unair.

Sugiyono, 1999 : Metode Penelitian Bisnis, Bandung : CV. Alfa Beta.

Suharsimi Arikunto, 2006 : Prosedur Penelitian Suatu Pendekatan Praktik, Jakarta : Rineka Cipta.

Suharyono, 1999 : Gastroentrologi Anak Praktis, Jakarta : Balai Penerbit FKUI.

Suliha, U., dkk, 2002 : Pendidikan Kesehatan dalam Keperawatan, Jakarta : EGC.

Sunaryo, 2004 : Psikologi untuk Keperawatan, Jakarta : EGC.

Suraatmaja, S., 2005 : Gastroentrologi Anak, Jakarta : CV Sagung Seto.

Wong, D., 2008 : Buku Ajar Keperawatan Pediatrik, Jakarta : EGC. 